\title{
Time to Think about Human Right to the Internet Access: A Beitz's Approach
}

\author{
Xiaowei Wang ${ }^{1}$ \\ ${ }^{1}$ Ethics Institute, Utrecht University, Utrecht, Holland \\ Correspondence: Xiaowei Wang, Ethics Institute, Utrecht University, Janskerkhof 13A, 3512 BL, Utrecht, \\ Holland. E-mail: t.wang@uu.nl
}

Received: March 31, 2013 Accepted: April 19, 2013 Online Published: August 30, 2013

doi:10.5539/jpl.v6n3p67

URL: http://dx.doi.org/10.5539/jpl.v6n3p67

\begin{abstract}
In this paper, I provided a justification for human right to the Internet access by using Beitz's theory of human rights. Contrasting to the naturalistic human rights theory that place the normativity of rights on a group of basic values that are derived from the universal human nature, the practical concept of human rights proposed by Beitz grounds the normativity of human rights concept on both the basic interests that are supposed to protect and the political role it is expected to play in current human right practice. I argued that Beitz's conceptualization of human rights is much more inclusive for new potential rights, as his human rights theory gives great deal of normative weight to the actual human rights practice. Since the current human rights practice in political arena strongly suggests the human right to the Internet access, I tested the potential human right to the Internet access through the criteria composed by Beitz, and argued that Beitz's theory could be very supportive for arguing human right to the Internet access.
\end{abstract}

Keywords: human rights, internet access, naturalistic theory, practical concept

\section{Introduction}

In 2010, French court refuted a request to cut off Internet access for people who download pirate music and software by claiming that Internet access should be seen as a basic human right. (Note 1) In Estonia, in the year 2000, the parliament declared a law that Internet access is a human right, as it is essential to meaningful human life in $21^{\text {st }}$ century. (Note 2) In Finland, by July 2010, the Internet access is legalized as a civil right that everyone should have an access to one-megabit per second bandwidth connection. (Note 3) Noticeably, the UN recently attempted to regard the Internet access as a human right, for its great positive impact on political change in the so-called "Arab spring" has been internationally acknowledged. (Note 4) As the rapid development of globalization and the information society, more and more people have been given Internet access around the world. The cooperation is now done in such a global scale that could never have been imagined without the use of the Internet. It cannot be exaggerated, as it is regarded by UN, to think our everyday life is so much shaped and changed by this technology that one cannot even live without it in our modern society. This trend could be clearly reflected by the poll done by the BBC that covers 26 countries. It showed that half of the interviewees strongly and almost $30 \%$ of people somewhat agree that the Internet access is a basic human right. This result is however stunning as it at least indicates the public inspiration to value the Internet access as a human right is very high. Legalists even started to explore the possibility of using the human right to the Internet as the legal framework to deal with legal cases concerning the use of the Internet (Lim \& Sexton, 2011) .

Despite the stir in the political and legal area, for mysterious reasons, few philosophical attempts were made specifically concerning this topic. In this paper, I proposed a Beitz's approach to accommodate the human right to Internet access. Contrasted to the naturalistic theory as Beitz described, I argued that Beitz's most recent practical conceptualization of human rights concepts opens the great theoretical possibility to justify the human right to the Internet access. I, firstly reviewed a few arguments that have been done concerning human rights to the Internet. Secondly I presented the argumentative framework of Beitz's conceptualization of human rights, and then identifies where the normativity of his theory originated. In doing so, I used Beitz's criteria for testing if the candidate human rights to the Internet could be qualified as a meaningful human right in Beitz's theoretical framework. 


\section{Human Right to the Internet Access? Argued and Contested}

Vinton Cerf (2012), who is regarded as one of the inventors of the worldwide website, made a public claim that it is a mistake to regard the Internet as a human right, as the 'technology is an enabler of rights, not a right itself. Vinton argued that in the ancient time people might need a horse to make a living, but it would be absurd to defend a human right to own a horse, as it would be a burden to have it in today. So construed, he proposed we would better to shift our focus on the technology to the outcomes it tried to ensure. It is these values, i.e., freedom of speech or freedom of access to information that makes this technology valuable, rather the technology should be valued for its own sake. To see the Internet as a human right is excessive, as quoted from Vinton, 'There is a high bar for something to be considered a human right. Loosely put, it must be among the things we as humans need in order to lead healthy, meaningful lives...' It seems that Vinton's argument implicitly made an assumption that human rights must be minimalistic and transhistorical. No matter how strong this assumption echoed with our intuition, it still should be verified. More or less in the same line, Brian Skepys (2012) made the most recent attempt to argue there is no such a thing called human right to the Internet access. He took a specific understanding of human rights along with Rawls and Cohen, seeing them as membership rights that are instrumentally necessary for the membership. Since which objects are significant for maintain the membership should be subjected to public reason, one could imagine different communities might value different objects. In this line, he argued the Internet access might be valuable for membership, and yet it is not necessary for it. All considered, it is not a human right in itself. The problem of this argument is, by taking Rawls and Cohen's conceptualization of human rights for granted, it naturally adopt an extreme lean list of human rights and thus failed to address the actual human rights practice, as I shall argue.

Best (2004) made the explicit attempt to argue for the right to the Internet is a human right in and of itself. His argument is twofold. First, he argued that the Internet is the technology that has been proven as the important tool for critical objectives as democracy and empowerment, thus it is instrumentally very important. Second, he moved further to argue that since the Internet is required by the symmetric information right, (Note 5) it is qualified to be a human right. However, in his eight pages paper, he was not able to provide a systematic argument rather than simply present the question, and there were surprisingly few follow up papers were composed.

\section{The Naturalistic Justification and the Human Right to Internet Access? A Glimpse}

So far there have been sadly few explicit attempts made to justify the possibility of the human right to the Internet by naturalistic philosophers. (Note 6) Thus I am not able to deal with the specific arguments, yet, I would try to postulate the difficulty that the naturalistic philosophers might face for justifying the human right to the Internet access. The naturalistic justification, as Beitz argued, gains its name for its specific justificatory framework that places the normativity of the human rights on a group of universal human values that might be specified from the universally shared human natures. (Note 7) Since the nature of the human rights should be austere enough to be possibly universalized, the values that are specified from it must necessarily be basic. Human rights are either the specification of the basic values or the most necessary means that are used to protect these values. The naturalistic human rights theories thus are generally hostile towards the inflation of human rights, as they see it the inflation would consequently dilute the authority of this particular concept that is of great normative significance. Taking Griffin's most recent conceptualization of human rights for instance, Griffin (2009) started with an austere human nature that is the capacity of forming a reflective life plan, and then specify three basic values out it, namely value of basic autonomy, liberty and welfare. Human rights are tools for protecting these values. In this case, the Internet access is surely not the necessary material for securing an austere human life. The difficulty of justifying a human right to the Internet for the naturalistic theories thus lies in proving the necessity of having the Internet access for protecting our most basic values that are essential for our normative human nature. This exploration is to a large extent a sociological question which cannot be fully settled without the input from public deliberation and academic effort. Yet, Beitz's conceptualization of human rights might make the human rights list more inclusive to the current political practice. Instead of exclusively, although he did it partly, deriving the normativity of human rights concept from its usefulness and urgency for protecting our basic interests, he also sees the actual political human rights practice as normativity giving. Thus, his justification has certain merit to include human rights to the Internet, for the current human rights practice in political and legal arena strongly suggests this move. Let's specify more in details by carefully presenting Beitz's argumentative framework. 


\section{Beitz's Conceptualization of Human Rights Concept}

Contrasted to the naturalistic theory of the human right which based the normativity of the concept on the concern of a particular group of the selected basic normative human values; and the agreement theory that built the normativity of the human rights concept on the mere political agreements, Beitz (2011) proposed a political concept of the human right that relies the justification of it on the specific political role it is expected to play in the international community.

Beitz drew his inspiration from John Rawls' book The Law of The People. In this book, Rawls (2001) proposed a very lean human right list that covers only a few items as an authentic human right, such as the right to life and right to the property...In this list, many important human rights that are enclosed by the UDHR are simply excluded, including some of the salient ones, such as the right to the freedom of the speech. The reason why the lean list of human rights instead of the others was proposed is largely due to the specific role of the human rights concept that is ascribed by Rawls. The human rights concept is just the one elements of the public reason that is used to justify the international interference, in most extreme case, even a just war. (Note 8) Beitz reflected on Rawls's approach to the human right concept and abstracted the rationale that is implicitly assumed in the Rawls approach that the conceptualization of the human rights should be related to its specific role it might play in the international politics. (Note 9) Yet, Beitz was not satisfied with Rawls approach to the human rights as his truncated human rights list certainly failed to grasp the dynamics of our contemporary international human rights practice (Note 10). It is obvious that the UHDR embraces much more diverse human rights than that of the Rawls's list. Considering this, Beitz reconstructed Rawls' approach of the human right and made the human rights list much more open for potential candidates rights.

Beitz acknowledged along the line with Rawls that the conceptualization of the human right should be related to its expected political role, and yet he made a novel methodological turn that the expected social role should also be seen as the normative basis (partly) for justifying and specifying the content of the human rights concept (Note 11). To be more precise, the expected role of the human rights would give its normative weight and help to identify what concerns could be categorized as the concern of the human rights. In Rawls attempt, this rationale is only implicitly assumed but not so well reflected as the methodology with the certain kind of the epistemic characteristic in Beitz's attempt.

Beitz's argument started with, along the line with Rawls, setting a political goal, namely the goal to achieve the international peace. For achieving this specific political goal, the concept of the human rights is required to play an important role in the public reason for justifying the international interference. This role, in turn helps to determine the content and the characteristics of the human rights (Note 12). By making this reconstruction, Beitz made his approach to a fresh start which is radically different from the naturalistic theory of the human rights in the way that it reversed the methodology of the justification. As Beitz argued, the naturalistic theories usually hold that the normative weight of the human rights shall be acknowledged once the content of the human rights are specified, he instead, argued alternatively that once the political role of the human rights expected to play is fixed, the content could be specified.

In Rawls work, the political goal that is expected to be achieved by the international justice is the international peace and collaboration. To achieve this goal gives us the great incentive to embrace a regulative authority in the international community, and this authority justifies the need to conceptualize the human rights as a tool for the international regulation. Concerning the proposed political goal is very minimalistic, as it is used for striving for the peaceful coexistence rather than the prosperity, the political role is mainly defined for justifying the membership of the International community or in the extreme case the just war. The society where the human rights are grossly violated is, in Rawls' term, the outlaw society which is disqualified as the member of the international community and deserve the punitive actions. Thus, in Rawls opinion, the content of the human rights is rigidly restrained by its specific role, which is fundamentally, justified by the fixed political goal it meant to achieve.

When it comes to Beitz, besides inheriting the political goal Rawls has articulated, he also gives great normative weight to the current human rights practice, seeing the actual practice as one of the normative footholds we should take to reconsider the conceptualization of the human rights. In other words, Beitz took the explanatory power of the human rights concept as one part of its justification, as the very goal of him is to find a theory that could accommodate the dynamic of the current human rights practice. Surely, the current human rights practice is much different from what Rawls has expected, as the human rights list embraced by the UN has much more volume. Clearly, as the political goal that is expected to be achieved by the use of the human rights concept in 
the current practice is not that minimalistic, thus, the conceptualization of the human rights concept should be reconsidered again.

Noticeably, the role of the human rights concept that is supposed to be shared by both Rawls and Beitz, is the role for justifying the international interference. However, the urgency of the reason that causes the international interference is diluted in Beitz' approach. By Rawls, the gross violation of the human rights would give reason for the international interference because it would potentially endanger the international peace. Yet, in Beitz's approach, the reason could be much less serious. As the current human rights practice allowed Hilary Clinton to criticize the China's Internet policy based on the concern of the human right to the freedom of the speech, Beitz's theory might allow people to take this practice for granted as the solid reason to think about possible international interference. So construed, he argued for a more inclusive conception of the human rights.

The less minimalistic goal gives less urgent reason for the practice of the human rights. Although the political role that is supposed to be carried out by the concept of the human right is fixed as for justifying the international interference, the reasons for carrying out an interference has become less urgent, and moreover, the very term of the international interference is readdressed and specified more by Beitz for being adaptive to the refined role. The international interference concerns various methods, including providing the international aid, economic sanctions, etc, through the current available means constructed by the human rights institutions. (Note 13)

\section{The Normativity of Beitz's Theory and the Human Right Criteria}

To reiterate, Beitz's approach consists of four important concepts: (i) the political reality (ii) the expected political goal; (iii) the expected political role; (iv) the human rights. The political goal that is derived from the political reality determines what is the role that should be carried out by the human rights. Furthermore, the very political role would helps to partly settle the content and the normative weight of the human rights concept. In this framework, the normativity of the human rights concept partly dependents on its political role which is justified by the political goal that is derived from the grasp of the political reality. Thus, the political reality (the current human rights practice) is one of the very normative sources. However, it seems that Beitz also sees the very political goal as having the ultimate normativity, since he affirmed that for the consideration of the goal could direct and even correct the current human rights practices. The normativity of Beitz's theory comes from both the political reality and the political goal. The former often gives us the prima facie reason to consider some political concerns as the human rights concern while the later gives the final justification.

Structured in this way, Beitz proposed that "a facially plausible justification for a claim that human rights doctrine should incorporate some specific protection should make good at least three types of claim. These are (i) that the interest protected has a kind of importance that it would be reasonable to recognize across a wide range of possible lives; (ii) that in the absence of the protections embodied in the right, there is a significant probability that domestic level institutions will behave, by omission or commission, in ways that endanger this interest; and (iii) that there are permissible means of international action such that, if they were carried out, the interest would be less likely to be endangered and that these means would not be unreasonably burdensome for those who have reason to use them." (Note 14) These four features could be seen as the criteria for qualifying one specific normative concern as a human right concern. The standard threat means, as Beitz quoted from Henry Shue, is 'a threat which is reasonably predictable under the social circumstances in which the right is intended to operate.' (Note 15) This stipulation thus excludes many other kinds of threats, for instance the arbitrary threat caused by the natural disasters, and makes the standard threat particularly related to our modern society.

Beitz's conception of the most urgent interests means that the interests that could be reasonably seen as important in a wide range of typical lives that occurs in contemporary societies. These interests are generalized from a kind of overlap among various international human rights doctrines. These interests are not seen as universal in the way everyone should necessarily accept them simply because they derived from the universal human nature as what is proposed by the naturalistic theories. Actually people do not even have to value them by themselves, what really is required is that they would have the least rationality to understand these values might be significant for others living in contemporary society. (Note 16) Beitz recognized that there is the need to identify the threshold of the urgency, as it is required to draw a line between the concern for human rights and non human rights. However, he refused to give any principle for identifying the threshold, as he believed in a practical approach that only in concrete cases could one consider all relevant factors and make a reasonable judgment. As he pointed out that: 'A model can draw attention to the relevant considerations but it cannot settle the judgments.' (Note 17) By doing so, Beitz tried to distance himself from the commitment to any moral theories of human interests. Nevertheless, as he didn't specify on this point in much detail, his discussion on the interests is still unclear and controversial. Beitz's conceptualization of the urgent interest seemingly implies a 
certain kind of the optimism, as he has much confidence that the diverse agents would finally converge on some urgent interests, and this concept of urgent interests gives his theory normativity as the second source. If we consider our political reality, it is simply the case that the normative considerations of the majority states indeed overlap on some points, and this overlapping consensus gave rise to the wide adoption of UDHR.

\section{The Test of the Human Right to the Internet by Beitz's Criteria}

As shown above, it is the trend today to discuss the potentiality of the Internet access as a candidate human rights in the political and legal arena. Considering the actual human rights practice, by Beitz, this would provide a prima facie reason to consider the normative necessity to embrace such a right in the first place. (Note 18) In the second place, we should subject this candidate human rights to the test by the three standards Beitz has proposed in order to fully comprehend if this right could be compatible or necessary for achieving the settled political goal.

\subsection{The Test (i)}

As shown above, Beitz held that only the most urgent human interests that are endangered by the standard threats could be seen as a possible human rights violation. When it comes to the human right to the Internet access, the question thus could be formulated as: Positively considered, if the use of the Internet access would significantly contribute into the protection of our most urgent interests against standard threats, or negatively considered, depriving someone of his Internet access would severely endanger his most urgent interests, then we have good reason to see this right as a candidate for human rights.

The rationale is simple: (i) If one sees $\mathrm{A}$ as the human rights, and he acknowledged that $\mathrm{B}$ is the indispensible tool to achieve A. (ii) He might have good reason to see B as a human right too. Nevertheless, having good reason to consider $\mathrm{B}$ as a human right is not equal to $\mathrm{B}$ should necessarily be seen as a human right. Since the normative weight of $\mathrm{B}$ dependents on the $\mathrm{A}$ and this dependence might change during the time. Thus $\mathrm{B}$ might not be seen as a human right but only the enabler of the right in specific period of time. The problem of this reductionist reasoning is that it seriously neglected the urgent need of the specification of basic human rights in current human rights practice, but overwhelmingly emphasizes on a few most basic human rights. By this standard, the human rights list would be much leaner than the list of UDHR (Universal Declaration of Human Rights). It would surely be excessive to talk about human right to democracy, or education in this particular reductionist understanding, not even to mention the human right to paid vacation. However, the current human right practice has been telling us that there is an urgent demand to specify human rights in order to reduce the confusion and ambiguity. In reality, one might find it is very difficult to really understand what is the human right to freedom of speech, if it is not specified as the human right to the press as it is listed in the American Bill of Rights. Or, one might not be fully understand the human right to autonomy without being offered the right to democracy. Particularly in the information age where many facets of our life have been undergoing great changes, the time presses us to specify our basic human rights by the changes of our society in order to fully accommodate the challenges of the ambiguity, vagueness, and makes the International human rights practice feasible.

The focus thus is about how the use of the Internet will be related to our most urgent interests in the way it would protect it against the standard threats. In fact, this particular technology has thrilled many scholars as the one that has its deeply integrated emancipatory characteristics. A large amount of research has been done concerning its potential to transform our way of doing politics with respect to the practice of the freedom of speech and democracy. There is nothing new to argue that the use of the Internet would facilitate us to exercise our human right to the freedom of speech. The arguments are in general threefold: firstly, compared to others medias, the Internet, gives us a new space in which we could express ourselves (Castells, 2008; Dahlberg, 2001; Gimmler, 2001; Papacharissi, 2002; Poster, 1997). Particularly in the state where the traditional medias are tightly controlled by the government, the cyberspace might work as the only space where the dissenting voice could be expressed (Eickelman \& Anderson, 2003; Zheng \& Wu, 2005); secondly, the right to freedom of speech could be better achieved by having the Internet, as the individuals are empowered to have their own weblog and express themselves in the most efficient way (Khiabany \& Sreberny, 2007; MacKinnon, 2008); Last but not least, the use of the Internet might makes one's expression matter more, as the use of the social media might help to increase the social capital that would contribute into the political participation (La Due Lake \& Huckfeldt, 2002; Skoric, Ying, \& Ng, 2009). The right to freedom of speech certainly is not just about expression, yet, it also assumes that the expression should matter. Otherwise this right does not bear that much normative weight. The freedom of speech argument could be further expanded to the concern of democracy. As the right to freedom of speech is either seen as the premise of the democracy, or one of the rights that should be protected because of the 
democracy, the practice of this right would significantly contribute to the protection and promotion of democracy. In particular, witnessing how the Internet is used in the so-called Arab Spring movement, many researches are able to show us the important role that is played by the Internet in the process of the democratization in Arabic world (Aouragh \& Alexander, 2011; Howard \& Hussain, 2011). Surely, there are many other approaches to relate the use of the Internet to our most urgent interests, i.e., the human right to the technology or information as it is proposed by Best, yet, it is, however, beyond my intention to cover all of them here. In addition, the sociological researches that are done so far cannot be seen as comprehensive enough to be conclusive. Due to the very versatility of the technology and the difference of circumstances in which it is used, there are hardly any conclusive answers could be drawn. However, despites their openness for the contestation, the sociological researches are strong enough to give us much confidence to recognize the Internet's positive impact on the practice of the freedom of the speech and the democracy.

Both the interest of democracy, freedom of speech and interest of accessing technology are included in the Universal Declaration of Human rights. (Note 19) The interests that are embraced by this most influential human doctrine give the prima facie reason to justify them as the most urgent human interest by Beitz's standard. Yet, Beitz would refuse to give the further justification aiming at identifying the ultimate principles to justify these urgent interests, as he believed this question could only be solved through the public communication in concrete context.

\subsection{The Test (ii)}

By Beitz, the second standard illustrates the vulnerability of such urgent interests in face of the power of the state. As to what I have shown, as the Internet is widely argued to be of great significance for protecting our most urgent interests, it derives its great normative weight from its instrumentality. Considering the second standard, the focus is to explore whether the Internet access is very vulnerable to the power of the state. My answer to this is simply yes. In the non-democratic state, take China for example, the Internet access is extremely vulnerable to the power of the central authority. As all the telecom companies are state owned, and little foreign capital is taken in the telecom business, China is able to keep the Internet business under state control (R. J. Deibert, 2002; Lum, 2006; Xiaoming, Zhang, \& Yu, 1996). The government is fully capable of filtering, censoring, manipulating or completely blocking the some information online. In some extreme cases, the Internet access could be fully eliminated.

On the other hand, the governments are often the most important agent for developing the Internet infrastructure, as it demands great investments in national infrastructure that does not introduce much profit in the short term. Particularly in the countries where the market is not mature, the central government becomes the only agent that could bear the investment. The early spread of the Internet in many countries depends very much on established telephone line infrastructure that is often listed as the project of the national infrastructure investment. For instance in the Africa, the sociological researches are able to show the penetration rate of the Internet access is positively related to the telephone density (Oyelaran-Oyeyinka \& Lal, 2005). The Chinese government is surely the only agent which invested in the telecom business in the early stage, and made the most use of its well-established post system for rolling out the Internet infrastructure (Tan, Foster, \& Goodman, 1999). The spread of the Internet access, even in a developed country such as US, the state played a very important role in it. The very technology in its beginning is widely know initiated as a military project, and it was under the pressure of the joint force of companies and researchers that the government decided to make it commercial (Chadwick, 2006). So far, most of nations have initiated their own plan for prompting the spread of the Internet access, and these plans were given such a priority that seemingly everyone saw this technology as a great opportunity to upgrade the national industries.

Other than as the main agent for prompting the Internet business, noticeably the state are the main agent, surely not the only agent, who has authority to enact policies that might regulate the Internet in the specific way. The state's regulation of the Internet mainly concerns the illegal content in cyberspace. There is nothing new to hear about the Arabic countries tried to filter and block some information under the consideration of their cultural integrity. In general, most of the democratic countries have made the specific attempt to regulate the online content. Countries like Australia developed a blacklist system that is mainly used to fence out pornography (Bambauer, 2009). The contradictory online content usually directly challenges the public good that might root in one nation's history and its particular culture, it is hard to imagine an agent other than the state that has the authority to address these questions. (Note 20) In addition, as the regulation of the online contend might require a consistent and joint effort, the state as the central authority surely has its merit to carry this task. To block the illegal downloading in one province of the state decided by the local authority would certainly not work out, as the people could soon smuggle the content from others whose local authority allowed this act. In particular, 
concerning the end-to-end feature of the Internet, it poses the necessity to have an international regulation, and this work, with the absence of the world government, can only be done by the joint effort of the national governments.

To sum it up, the Internet is in general very vulnerable to the governmental actions, as its development and content are both largely influenced by the government investment and regulation.

\subsection{Test (iii)}

By Beitz, we should also consider if there are means that could be used to carry out International actions with affordable cost. Currently, Hilary Clinton had made a speech condemning China's Internet policy. This is, however, not the first time that the US has made this effort. Various politicians have expressed their concern about Internet freedom in China. These efforts might reflect the great change of perception of the foreign policy. The Value-based Diplomacy, despite its controversy, indeed grasps some characteristics of the change. As it is affirmed by the EU policy, committing to the protection of the human rights is the premise to be considered as the qualified member, (Note 21) the human rights concern could be properly related to the foreign polices that covers a wide range of the international cooperation. The violation of the human rights could pose problems for the further business cooperation, and this cooperation might not be the one anticipated by Rawls as the minimal standard for maintaining peace, but for fulfilling great economic prosperity. (Note 22) The political practice has indicated this possibility, and it is more or less the reality as well. In fact, there are many possibilities to relate the concern of the human right to Internet to the concern of the foreign diplomacy, thus the attempt should not be limited to business cooperation.

The UN's role in the development and spread of the Internet could give us much insight concerning the means of the international actions. The Untied Nations, as the unique agent, has been leading to stimulate the telecommunication development around the world through various means (McPhail, 2009). The Human Rights Council has the unique authority to evaluate and criticize its member's human rights fulfillment, and in most extreme cases justify an international war. In the less extreme case, the UN is authorized to issue a human rights report condemning the state which is accused of human rights violations. In the situations where the state is incapable of protecting human rights, the UN would be required to, and it is also capable of, providing the a necessary aid.

Besides the UN's effort, diverse international agents have been involved in the progress of the facilitating the prompting of the spread of the Internet. The World Bank and IMF, for instance, have been carrying out numerous projects for funding telecom projects in various nations. The National computing and Networking Facility of China, for instance, was initiated and was financially supported by the World Bank. These agents are particularly ideal for bearing this responsibility as the very goals embedded in their establishment is public interests orientated. In addition, the membership of these world organizations is based on the recognition of the state sovereignty, meaning that the board members are representatives of their own nations. (Note 23) These institutions are, to some extent, very capable of pressing and prompting the protection of human rights, as they have great sources at their disposal. Since both of these organizations have their consideration of the conditionality, the selection of the recipient countries could be made by specifically designed standards that might relate to the human rights protection. The urgent human rights demand should be fulfilled as the top priority, and moreover, the gross violation of the human rights might result in the disfavor of the financial aid.

\section{The Problem: The Statist Approach and the Internet, a Potential Conflict}

It is obvious that Beitz held a statist understanding of the human rights, (Note 24) as his approach is based on the current international politics in which states play the dominate role. The state government is seen as both the protector and potential perpetrator of human rights, and no other agents are considered. So far I have elaborated on how Beitz's conceptualization of human rights would be congenial to the human right to the Internet access. Nevertheless, Beitz's statist understanding of the human rights might also pose a great challenge for embracing the human right to the Internet, as the statist view of human rights would be not able to fully comprehend the very anarchistic feature of this technology. By Beitz, the only legitimate agents that could regulate the human rights might still be exclusively the sate government. Nevertheless, the fact is the regulation of the Internet in the global scale is not fully controlled by the government, and yet many essential Internet resources are controlled by NGOs. Therefore, the statist conceptualization of the human right to the Internet might not be able to involve these NGOs. Since these NGOs have great controlling and managing power over the Internet, it would certainly be problematic to exclude them as the potential agent to protect or violate the human right to the Internet access. (Note 25) Neglecting this point, one might find the current the International regulatory means that are constructed along the state sovereignty certainly are not able to fully address the possible violation of the human 
right to the Internet access. As possibility of identifying the feasible means to correct the human rights violation is seen as one of the standards of judging the candidate human right, the statist approach of the human rights might arrive at a conclusion that the feasible means of protecting the human right and correction of the violation are lacking, and this, as a result, would disqualify the human right to the Internet access.

Despite this challenge, Beitz's methodology to approach human rights might still provide a possibility to address the problem. As what I have presented, the whole Beitz's argument started with the normative affirmation of the political reality. His effort is to find the human rights theory with the strongest explanatory power for explaining current human rights practices. The current human right practice in fact already indicated the involvement of non-governmental agents. Both the UN and the World Bank have successfully managed to include NGOs in its meetings in order to forge a liaison, and it is the trend and fact that more and more NGOs would probably be involved in the future and the more weight they will get (Alger, 2002; Goldman, 2006; Gordenker, 1995; Otto, 1996). On the flip side, the NGOs, for instance ICANN, also tried to involve the voice of national governments, if the global interests are in concern. (Note 26) Nevertheless, if we stick to Beitz's methodology, much theoretical effort needs to be made in order to accommodate this change. I shall in anyway stop my postulation here, for this exploration goes beyond the scope of this piece.

\section{Conclusion}

To sum it up, as to what I have presented above, the current human rights practice in politics gives us a prima facie reason to seriously consider the human right to the Internet access; in addition, the candidate human rights to the Internet could possibly pass the test of Beitz. If my argument is sound, we might have good reason to embrace the human right to the Internet. However, I shall limit my discussion right to this point with no ambition to defend a strict position that the Internet access is at the moment an undoubtable human right. As to whether or not the Internet access is relevant to our most urgent human interests is an empirical question that might change with the tide, no conclusive answer could be drawn to this point and one should wisely leave it to the public debate. Moreover, it seems there are certain dangers coming along with the wide adoption and deep integration of the Internet technology in our daily life. The problems of the illegal downloading, Children pornography, hate speech so on and so forth, might severely endanger some of our basic interests. If this is the case, it might require us to weigh between the gains and the loss of using the Internet. In spite of this methodological prudence, we still could positively anticipate that the use of the Internet would bring us more positive rather than negative results based on the immediate grasp of the reality. This thread of the positivism is not blind whatsoever; it is open for correction and contestation.

\section{Acknowledgements}

I want to thank Professor Marcus Duwell for his sharp comments on the draft of this paper, and Verona Clark for smoothing out the text. Without their help, this paper could not be developed as what it is now.

\section{References}

Alger, C. (2002). Emerging Roles of the NGOs in the UN System: From Article 71 to a People's Millennium Assembly. Global Governance, 8, 93.

Aouragh, M., \& Alexander, A. (2011). The Egyptian experience: sense and nonsense of the Internet revolution. International Journal of communication, 5, 1344-1358.

Bambauer, D. E. (2009). Filtering in Oz: Australia's foray into Internet censorship. U. Pa. J. Int'l L., 31, 493. http://dx.doi.org/10.2139/ssrn.1319466

Bäßler, L. (2011). ICANN - The Organization and Governance of the Internet. GRIN Verlag.

Beitz, C. R. (2011). The Idea of Human Rights. OUP Oxford.

Best, M. L. (2004). Can the internet be a human right. Human Rights \& Human Welfare, 4(1), 23-31.

Castells, M. (2008). The new public sphere: Global civil society, communication networks, and global governance. The ANNALS of the American Academy of Political and Social Science, 616(1), 78-93. http://dx.doi.org/10.1177/0002716207311877

Cerf, V. G. (2012). Internet access is not a human right. New York Times, 5.

Chadwick, A. (2006). Internet politics: states, citizens, and new communication technologies. Oxford University Press. 
Dahlberg, L. (2001). The Internet and democratic discourse: Exploring the prospects of online deliberative forums extending the public sphere. Information, Communication \& Society, 4(4), 615-633. http://dx.doi.org/10.1080/13691180110097030

Deibert, R. (2008). Black code redux: censorship, surveillance, and the militarization of cyberspace. Digital media and democracy: tactics in hard times, 137-164.

Deibert, R. J. (2002). Dark guests and great firewalls: The Internet and Chinese security policy. Journal of Social Issues, 58(1), 143-159. http://dx.doi.org/10.1111/1540-4560.00253

Eickelman, D. F., \& Anderson, J. W. (2003). New media in the Muslim world: the emerging public sphere. Indiana University Press.

Gimmler, A. (2001). Deliberative democracy, the public sphere and the internet. Philosophy \& Social Criticism, 27(4), 21-39. http://dx.doi.org/10.1177/019145370102700402

Goldman, M. (2006). Imperial Nature: The World Bank And Struggles for Social Justice in the Age of Globalization. Yale University Press.

Gordenker, L. (1995). NGO participation in the international policy process. Third World Quarterly, 16(3), 543-556. http://dx.doi.org/10.1080/01436599550036059

Griffin, J. (2009). On Human Rights. OUP Oxford.

Howard, P. N., \& Hussain, M. M. (2011). The role of digital media. Journal of democracy, 22(3), 35-48. http://dx.doi.org/10.1353/jod.2011.0041

Hunter, D. (2002). ICANN and the Concept of Democratic Deficit. Loy. LAL Rev., 36, 1149. http://dx.doi.org/10.2139/ssrn.400000

Khiabany, G., \& Sreberny, A. (2007). The politics of/in blogging in Iran. Comparative Studies of South Asia, Africa and the Middle East, 27(3), 563-579. http://dx.doi.org/10.1215/1089201x-2007-033

Klein, H. (2001). The feasibility of global democracy: understanding ICANN's at-large election. info, 3(4), 333-345. http://dx.doi.org/10.1108/14636690110801996

La Due Lake, R., \& Huckfeldt, R. (2002). Social capital, social networks, and political participation. Political Psychology, 19(3), 567-584. http://dx.doi.org/10.1111/0162-895X.00118

Lim, Y. J., \& Sexton, S. E. (2011). Internet as a Human Right: A Practical Legal Framework to Address the Unique Nature of the Medium and to Promote Development. Wash. JL Tech. \& Arts, 7, 295.

Lum, T. (2006). Internet development and information control in the People's Republic of China.

MacKinnon, R. (2008). Flatter world and thicker walls? Blogs, censorship and civic discourse in China. Public Choice, 134(1), 31-46. http://dx.doi.org/10.1007/s11127-007-9199-0

McPhail, T. L. (2009). Development Communication: Reframing the Role of the Media. Wiley.

Otto, D. (1996). Nongovernmental organizations in the United Nations system: The emerging role of international civil society. Human Rights Quarterly, 18(1), 107-141. http://dx.doi.org/10.1353/hrq.1996.0009

Oyelaran-Oyeyinka, B., \& Lal, K. (2005). Internet diffusion in sub-Saharan Africa: A cross-country analysis. Telecommunications policy, 29(7), 507-527.

Papacharissi, Z. (2002). The virtual sphere The internet as a public sphere. New media \& society, 4(1), 9-27. http://dx.doi.org/10.1177/14614440222226244

Poster, M. (1997). Cyberdemocracy: Internet and the public sphere. Internet culture, 201-218.

Rawls, J. (2001). The Law of Peoples: With "The Idea of Public Reason Revisited". Harvard University Press.

Santoro, A. (2011). Rt-China 2020 Z. Cornell University Press.

Skepys, B. (2012). Is There a Human Right to the Internet? Journal of Politics and Law, 5(4), 15. http://dx.doi.org/10.5539/jpl.v5n4p15

Skoric, M. M., Ying, D., \& Ng, Y. (2009). Bowling online, not alone: Online social capital and political participation in Singapore. Journal of Computer - Mediated Communication, 14(2), 414-433. http://dx.doi.org/10.1111/j.1083-6101.2009.01447.x 
Tan, Z. A., Foster, W., \& Goodman, S. (1999). China's state-coordinated Internet infrastructure. Communications of the ACM, 42(6), 44-52. http://dx.doi.org/10.1145/303849.303861

Xiaoming, H., Zhang, K., \& Yu, H. (1996). Internet and Information Control: The Case of China. Electronic Journal of Communication/La Revue Electronique de Communication, 6(2), 2.

Zheng, Y., \& Wu, G. (2005). Information technology, public space, and collective action in China. Comparative Political Studies, 38(5), 507-536. http://dx.doi.org/10.1177/0010414004273505

\section{Notes}

Note 1. Sarkozy government tried to enacted a law on strictly regulating illegal downloading private contend, which requires a special agency to be established to track and cut off internet access automatically if someone neglects the two warnings and constitute to download private content. In 2009, the French constitutional council declared access to Internet to be a basic human right, which makes it clear that only the law of court have the authority to cut off the net access. For the decision see http://www.conseil-constitutionnel.fr/conseil-constitutionnel/root/bank_mm/anglais/2009_580dc.pdf

Note 2. "Estonia, where being wired is a human right", Colin Woodard, Christian Science Monitor, 1 July 2003. Accessed Feb 2, 2012. http://www.csmonitor.com/2003/0701/p07s01-woeu.html

Note 3. "Finland makes $1 \mathrm{Mb}$ broadband access a legal right", Don Reisinger, CNet News, 14 October 2009. Accessed Feb 2, 2012. http://news.cnet.com/8301-17939_109-10374831-2.html

Note 4. In May 2011, in UN special Rapporteur on the promotion and protection of the right to freedom of opinion and expression, the uniqueness of Internet in protecting other human rights are stated: cutting of internet arbitrarily is considered as violation of civil and political right. It is suggested by UN all government should make effort to ensure Internet access is maintained all times, even in political unrest. Moreover, US reports made an empirical claim that Internet has become an indispensible tool for realizing a range of human right and henceforth, ensuring universal access to the internet should be priority to all states. Furthermore, it seems that UN is taking a step further to make a positive move, claiming " each state should develop a concrete and effective policy to make Internet widely available, accessible and affordable to all segments of population. Franck La Rule who composed the document "on the promotion and protection of the right to freedom of opinion and expression." went further to argue that the Internet access should be seen as the basic human right concerning its importance for protection and promotion of the freedom of speech or democracy. Yet, it was recognized by him that it is not feasible so far to expect the immediate fulfillment of this right. However, human rights, social and economic rights in particular, do not require an immediate but a progressive fulfillment. http://www2.ohchr.org/english/bodies/hrcouncil/docs/17session/a.hrc.17.27_en.pdf

Note 5. Symmetric information right is the term invented by Best to illustrate his revision of the information right, as he argued that asymmetrically emphasize on the freedom of expression while neglect the right to impression (to get information) is wrong.

Note 6. I am not saying that there are no attempts were made concerning the normative importance of the Internet by relating it to our basic human values, such as value of the communication or freedom of speech. What I am saying is there are not explicit efforts were made to deal with the question whether if the Internet access is an eligible human right.

Note 7. For detailed discussion on naturalistic justification, see Beitz, The Idea of Human Rights, p49-68

Note 8. Rawls, The Law of Peoples, pp 79-80

Note 9. Beitz, The Idea of Human Rights p 96-97

Note 10. Ibid. PP101-102

Note 11. Ibid. PP 102-103

Note 12. Ibid P105

Note 13. Ibid. P 101

Note 14. Ibid. P 111

Note 15. Ibid. P 111

Note 16. Ibid. PP109-112

Note 17. Ibid. P110 
Note 18. Ibid. P11

Note 19. See UDHR, Article 19: Everyone has the right to freedom of opinion and expression; this right includes freedom to hold opinions without interference and to seek, receive and impart information and ideas through any media and regardless of frontiers. Article 21: (3) The will of the people shall be the basis of the authority of government; this will shall be expressed in periodic and genuine elections which shall be by universal and equal suffrage and shall be held by secret vote or by equivalent free voting procedures. Accessed February 2, 2013, http://www.un.org/en/documents/udhr/

Note 20. There are two kinds of the public goods. The thin public goods are the goods that should necessarily be valued by all, for instance the public goods in the sense of Rawls's political liberalism. Without appreciating these goods, it is impossible for people to live in peace with each other. If the thin public goods are endangered, the government is surely the very agent that should carry out actions. For instance, after the 911 , the US government clearly supervise more strictly on the online information flow(R. Deibert, 2008). The thick public goods are embedded in one strong tradition or culture; thus, the state might be asked to act or not depends very much on how the state is organized. If the state is ideally organized by the principle of the political liberalism, the government should stay neutral towards these goods, other agents, for instance, the church, might be called up for action. In other case, if the state is organized in theocratic way, the government is surely expected as the main agent to act.

Note 21. Membership criteria - Who Can Join? Accessed Feb 2, 2013 http://ec.europa.eu/enlargement/policy/conditions-membership/index_en.htm

Note 22. On March 27, 2012, multiple agents including the Subcommittee on Africa, Global Health and Human Rights of the US House Representatives approved the Global Online Freedom Act of 2012. This act was expected to provide legislation for preventing the US companies to run the business with the governments who censored or filtered the free flow of the information online. This decision is also justified based on the concern of prompting the value of the freedom of speech. Accessed December 2,2012. http://chrissmith.house.gov/uploadedfiles/hr_3605_ans.pdf; European Parliament also made a proposal, if it is approved by the EU parliament, that the Internet censorship should be seen as a obstacle for maintaining the trade (Santoro, 2011).

Note 23. Confronted with the ever-increasing harsh critics, the World Bank has reformed to take in some NGOs; however, the national governments are still the dominating power.

Note 24. Beitz, The idea of Human Rights, p 128

Note 25. One of the most influential global authorities of regulating the Internet is ICANN (Internet Corporation for Assigned names and Numbers). ICANNwas originally established by the US government but gained its independent status in October 2, 2009. This organization has great authority over the Internet resources, as it is mainly responsible for the distribution of the IP address and the management of the DNS root zone. Despites its independent status as the non-governmental and public profit organization, ICANN maintained a particular tight relation with world's governments by the Governmental Advisory Committee(Bäßler, 2011). The structure of the ICANN represents a kind of global democracy in its early stage, as the representatives were selected by anyone who is willing to vote. However, the practice of the global democracy in ICANN was highly contested (Hunter, 2002). Since the ICANN controlled the particular resource of the Internet, ICANN also extend its power to the policy making process, for instance the matter of the property right, no matter how it is contestable. As Klein(2001) rightly pointe out: "Although ICANN's mandate is technical and administrative in nature, its decisions are inextricably linked to global public policy."

Note 26. ICANN has a specific committee GAC (Government Advisory Committee) for taking in governmental inputs. "The GAC's key role is to provide advice to ICANN on issues of public policy, and especially where there may be an interaction between ICANN's activities or policies and national laws or international agreements." Accessed Feb $\quad$ 2, 2013 https:/gacweb.icann.org/display/gacweb/Governmental+Advisory+Committee

\section{Copyrights}

Copyright for this article is retained by the author(s), with first publication rights granted to the journal.

This is an open-access article distributed under the terms and conditions of the Creative Commons Attribution license (http://creativecommons.org/licenses/by/3.0/). 